\title{
Isolation of Constituents with Nitric Oxide Synthase Inhibition Activity from Phryma leptostachya var. asiatica
}

\author{
Donghwa Kim ${ }^{1}$, Sang Kook Lee ${ }^{1}$, Kyoung-Sik Park ${ }^{2}$, Na-Yun Kwon ${ }^{3}$, and Hee-Juhn Park ${ }^{3}$ ** \\ ${ }^{1}$ College of Pharmacy, Seoul National University, Seoul 08826, Korea \\ ${ }^{2}$ College of Oriental Medicine, Sangji University, Wonju 26339, Korea \\ ${ }^{3}$ Department of Pharmaceutical Engineering, Sangji University, Wonju 26339, Korea
}

\begin{abstract}
Phytochemical studies were performed to identify the active principles of Phryma leptostachya var. asiatica (Phyrymaceae) for anti-inflammation. The anti-inflammatory activity was assessed by measuring the inhibition rate on nitric oxide (NO) formation in lipopolysaccharide (LPS)-activated macrophage 264.7 cells. Of the five compounds including ursolic acid, phrymarolin I, harpagide, haedoxancoside A, and acteoside isolated from this plant, ursolic acid showed the most prominent inhibition of NO formation. Therefore, ursolic acid may be the anti-inflammatory principle of Phryma leptostachya var. asiatica.
\end{abstract}

Keywords - Phryma leptostachya var. asiatica, Phyrymaceae, nitric oxide, anti-inflammatory, ursolic acid

\section{Introduction}

Phrima leptostachya var. asiatica (Phrymaceae) is a perennial herb growing in the shading place. This plant is distributed in Korea, Japan, and China as well as Siberia and North-East America. Paripul,the Korean name of this plant, was named because its root has been used to kill flies. In addition, this plant has been also used to treat allergic dermatitis and itching and to prevent cancer disease. ${ }^{1}$

The constituents of the lignans of phrymarolin I and $\mathrm{II}^{2,3} \mathrm{~V}$ and $\mathrm{B}^{4,5}$ possessing the basic structure of 1,2dioxygenated-3,7-dioxabicyclo[3.3.0]octane, haedoxancoside A belonging to sesquilignan, ${ }^{5}$ and ursolic acid as the triterpene $\operatorname{acid}^{6}$ were previously reported. Furthermore, the larvicidal activity ofleptostachyol acetate, a lignan of $P$. leptostachya var. asiatica, has been also reported. ${ }^{7,8}$

Nitric oxide (NO) is a simple and gaseous mediator produced by nitric oxide synthase (NOS) including inducible nitric oxide synthase (iNOS). NO is involved in pathophysiological conditions such as inflammatory- and autoimmune diseases. ${ }^{9}$ The expression of iNOS is induced by pro-inflammatory cytokines and bacterial lipopolysaccharide (LPS). ${ }^{10}$ Therefore, anti-inflammatory effect is assessed by measuring the amount of NO in lipopoly-

*Author for correspondence

Hee-Juhn Park, Ph.D, Department of Pharmaceutical Engineering, Sangii University, Wonju 26339, Republic of Korea

Tel: +82-33-730-0564; E-mail: hjpark@sangji.ac.kr saccharide (LPS)-induced murine macrophage RAW 264.7 cells.

Jung et al. ${ }^{1}$ reported that the root extract of $P$. leptostachya var. asiatica has anti-inflammatory effect via the mechanism of anti-oxidative and the inhibition of iNOS and cyclooxygenase-2 activities in LPS-activated macrophage cells. However, the active principle of $P$. leptostachya var. asiaticafor anti-inflammation has not been reported yet. Therefore, in the present study, we aimed to identify which compounds are mainly responsible for anti-inflammatory activity of this plant.

\section{Experimental}

Plant material - The whole plant of Phyryma leptostachya var. asiatica Hara (Phrymaceae), was collected from the mountain area in Wonju city, Gangwon-do, Korea. The plant was washed, dried, and cut for extraction. The plant was identified by Prof. Byung-Min Song, Department of Forest Science, Sangji Univerisity, Korea. A voucher specimen (natchem-\#87) was deposited in the Laboratory of Natural Products Chemistry, Sangji University, Korea.

Extraction and fractionation - The plant material $(892 \mathrm{~g})$ was extracted with $\mathrm{MeOH}$ (each, $5.0 \mathrm{~L})$ three times under reflux. The extracted solution was filtered and concentrated under reduced pressure on a rotatory evaporator. The viscous $\mathrm{MeOH}$ extract was further subjected to freeze-drying to give a solid $\mathrm{MeOH}$ extract $(123.0 \mathrm{~g}$, 
extraction yield $13.3 \%$ ).

The $\mathrm{MeOH}$ extract was suspended in $\mathrm{H}_{2} \mathrm{O}(2.0 \mathrm{~L})$, and partitioned with hexane $(2.0 \mathrm{~L})$ three times. The hexane fraction was further concentrated in vacuo to give a $\mathrm{CHCl}_{3}$ fraction $(24.0 \mathrm{~g})$. In the same method, the residual $\mathrm{MeOH}$ extract was successively fractionated with $\mathrm{CHCl}_{3}, \mathrm{EtOAc}$, and $\mathrm{BuOH}$, respectively, to give a $\mathrm{CHCl}_{3}$ fraction $(18.5 \mathrm{~g})$, EtOAc fraction $(4.55 \mathrm{~g})$, and $\mathrm{BuOH}$ fraction $(28.0 \mathrm{~g})$.

After that solvent fractionation, the hexane fraction was further fractionated by the column chromatography. The hexane fraction was developed over diaion HP-20 column chromatography with $1.0 \mathrm{~L} \mathrm{MeOH}$, and then eluted with

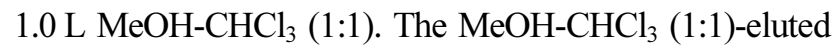
solution was concentrated in vacuo to yield a $\mathrm{MeOH}-$ $\mathrm{CHCl}_{3}$ fraction.

In addition, the $\mathrm{BuOH}$ fraction was further subjected to diaion HP-20 column chromatography to remove sugars and ionic substances. The $\mathrm{BuOH}$ fraction was washed with $\mathrm{H}_{2} \mathrm{O}(2.0 \mathrm{~L})$ over the column, and then eluted with $\mathrm{MeOH}(2.0 \mathrm{~L})$. The $\mathrm{MeOH}$ solution was concentrated to yield $8.29 \mathrm{~g} \mathrm{MeOH}$ fraction.

Isolation of ursolic acid (1) and phrymarolin I (2) The $\mathrm{MeOH}-\mathrm{CHCl}_{3}$ fraction obtained from the hexane fraction was subjected to silica gel column $(40 \mu \mathrm{m}, 165 \mathrm{~g}$, $48 \times 170 \mathrm{~mm}$, Hi-Flash column, Yamazen Co., Japan) chromatography using $\mathrm{CHCl}_{3}-\mathrm{MeOH}-\mathrm{H}_{2} \mathrm{O}$ (8:1:1, lower phase) and collected by each $50 \mathrm{~mL}$. After checking TLC, the fractions \#25-28 and \#36-39 were concentrated to afford PLA-\#25-28 and PLA-\#36-39, respectively. PLA\#25-28 was washed with $\mathrm{MeOH}$ to yield compound $\mathbf{1}$. PLA-\#36-39 was recrystallized from $\mathrm{MeOH}$ to yield compound 2. Compounds $\mathbf{1}$ and $\mathbf{2}$ were identified as ursolic acid (Lee et al., 2002) and phrymarolin I (Taniguchi and Oshima, 1972), respectively, by comparisons of ${ }^{1} \mathrm{H}-$ and ${ }^{13} \mathrm{C}$-NMR spectroscopic data with literatures.

Compound 1 (ursolic acid) - White powder, UV $\lambda_{\max }$ $\mathrm{MeOH}(\log \varepsilon): 220$ (2.83) nm; IR $v_{\max }(\mathrm{KBr}) \mathrm{cm}^{-1}: 3400$ (broad, OH), 1090(COOH); ${ }^{1} \mathrm{H}-\mathrm{NMR}(600 \mathrm{MHz}$, pyridine$d_{5}$ ) and ${ }^{13} \mathrm{C}$-NMR (150 MHz, pyridine- $\left.d_{5}\right) \delta$ : Literature. ${ }^{6}$

Compound 2 (phrymarolin I) - Amorphous powder, IR vmax (KBr) $\mathrm{cm}^{-1}: 3008$ (broad, OH), 1733 (ester), 1634, 1502 (aromatic $\mathrm{C}=\mathrm{C}$ ); ${ }^{1} \mathrm{H}-\mathrm{NMR}\left(600 \mathrm{MHz}, \mathrm{CD}_{3} \mathrm{OD}\right)$ and 13C-NMR (150 MHz, $\left.\mathrm{CD}_{3} \mathrm{OD}\right) \delta$ : Literature. ${ }^{2}$

Isolation of harpagide (3), haedoxancoside $A$ (4) and acteoside (5) - The $\mathrm{MeOH}$ fraction obtained by eluting the $\mathrm{BuOH}$ fraction over diaion HP-20 column with $\mathrm{MeOH}$ was subjected to silica gel column chromatography $(40 \mu \mathrm{m}, 165 \mathrm{~g}, 48 \times 170 \mathrm{~mm}$, Hi-Flash column, Yamazen Co., Japan) with the solvent of $\mathrm{CHCl}_{3}-\mathrm{MeOH}-$ $\mathrm{H}_{2} \mathrm{O}$ (65:35:10, lower phase), and collected by each
$50 \mathrm{~mL}$. After checking TLC, the fractions \#39-44, \#5058, and \#72-88 were concentrated, respectively, and precipitated from $\mathrm{MeOH}$ to yield compounds $\mathbf{3}, \mathbf{4}$, and $\mathbf{5}$. The three compounds $\mathbf{3}, \mathbf{4}$, and $\mathbf{5}$ were identified as harpagide, ${ }^{11}$ haedoxancoside $\mathrm{A},{ }^{5}$ and acteoside ${ }^{12}$ by comparisons of spectroscopic data with literatures.

Compound 3 (harpagide) - Amorphous powder frm $\mathrm{MeOH}, \mathrm{mp} 228-229$, IR $v_{\max }(\mathrm{KBr}) \mathrm{cm}^{-1}: 3358,1643$, 1250, 1047; 1H-NMR (600 MHz, $\left.\mathrm{CD}_{3} \mathrm{OD}\right)$ and 13CNMR $\left(150 \mathrm{MHz}, \mathrm{CD}_{3} \mathrm{OD}\right) \delta$ : Literature. ${ }^{11}$

Compound 4 (haedoxancoside A) - White powder, mp $181-183^{\circ} \mathrm{C}$, UV $\lambda_{\max }(\mathrm{MeOH}) \mathrm{nm}(\log \varepsilon): 293$ (4.05), 234 (4.08); IR $v_{\max }(\mathrm{KBr}) \mathrm{cm}^{-1}: 34783006,2941$, 1600, 1500; ${ }^{1} \mathrm{H}-\mathrm{NMR}$ (600 MHz, CD3OD) and ${ }^{13} \mathrm{C}-\mathrm{NMR}$ $(150 \mathrm{MHz}, \mathrm{CD} 3 \mathrm{OD}) \delta$ : Literature. ${ }^{5}$

Compound 5 (acteoside) - UV $\lambda_{\max }(\mathrm{MeOH}) \mathrm{nm}(\log$ ع) : 328 (4.11); IR $v_{\max }(\mathrm{KBr}) \mathrm{cm}^{-1}: 3403$ (broad, O-H), $1698(\mathrm{C}=\mathrm{O}), 1631$ (olefinic $\mathrm{C}=\mathrm{C}$ ), $1100-1000$ (glycosidic C-O); 1H-NMR (600 MHz, CD3OD) $\delta$ : Literature. ${ }^{12}$

Cell culture - Murine macrophage RAW 264.7 cells were obtained from the American Type Culture Collection (ATCC, Rockville, MD, USA), and cultured in DMEM supplemented with $10 \%$ heat-inactivated fetal bovine serum (FBS) and antibiotics-antimycotics (PSF; 100 units $/ \mathrm{ml}$ penicillin $\mathrm{G}$ sodium, $100 \mathrm{ng} / \mathrm{mL}$ streptomycin, and $250 \mathrm{ng} / \mathrm{mL}$ amphotericin B). The cells were incubated at $37^{\circ} \mathrm{C}$ under a humidified atmosphere containing $5 \%$ $\mathrm{CO}_{2}$.

Cell viability assay-After the supernatant was collected for iNOS assay, MTT solution (final concentration of $500 \mu \mathrm{g} / \mathrm{mL}$ ) was added to each well and incubated for $4 \mathrm{~h}$ at $37^{\circ} \mathrm{C}$. The culture media was aspirated, and dimethyl sulfoxide (DMSO) was added to dissolve the dye. The absorbance was measured at $570 \mathrm{~nm}$ using VersaMax ELISA microplate reader (Molecular Devices, Sunnyvale, CA, USA), and the percent survival was determined by comparison with a control group (LPS+).

iNOS assay - Murine RAW 264.7 cells were seeded in 24-well plates $\left(2 \times 10^{5}\right.$ cells $\left./ \mathrm{mL}\right)$. The next day, culture media were changed to $1 \%$ FBS-DMEM with sample treatment. After $1 \mathrm{~h}$, LPS $(1 \mu \mathrm{g} / \mathrm{mL})$ was added, except LPS- control, to stimulate NO production. The amount of NO production in culture media was determined by Griess reaction after $18 \mathrm{~h}$ incubation. Briefly, $100 \mu \mathrm{L}$ of culture media was collected per each well and $180 \mu \mathrm{L}$ of Griess reagent $(0.1 \% \quad N$-(1-naphthyl) ethylenediamine dihydrochloride in $\mathrm{H}_{2} \mathrm{O}$ and $1 \%$ sulfanilamide in $5 \%$ $\mathrm{H}_{3} \mathrm{PO}_{4}$ ) was added. The absorbance was measured at $540 \mathrm{~nm}$. The nitrate concentration was determined by 
Table 1. Effect of the $\mathrm{MeOH}$ extract of P. leptostachya var. asiatica and its fractions on NO formation in LPS-activated macrophage cells (test concentration of $40 \mu \mathrm{g} / \mathrm{mL}$ )

\begin{tabular}{ccc}
\hline \hline Sample & Inhibition rate (\%) & Cell viability (\%) \\
\hline MeOH extract & 41.0 & - \\
Hexane fraction & 63.8 & - \\
$\mathrm{CHCl}_{3}$ fraction & 48.3 & 26.4 \\
EtOAc fraction & 40.1 & - \\
BuOH fraction & 38.2 & - \\
\hline
\end{tabular}

Footnote: -, not cytotoxic

comparison with sodium nitrite standard curve. Percent inhibition was calculated using following formula: [1 (NO level of test samples/NO levels of vehicle-treated control)] $\times 100$. The $\mathrm{IC}_{50}$ value was calculated through non-linear regression analysis using TableCurve 2D v5.01 (Systat Software Inc., San Jose, CA, USA)

\section{Results and Discussion}

The iNOS is an enzyme responsible for the production of nitric oxide (NO). Recently, anti-inflammatory activity is frequently assayed by measuring the iNOS inhibition activity. ${ }^{13}$ In the present study, iNOS assay was performed to identify the anti-inflammatory compounds since the active compounds from $P$. leptostachya var. asiaticahave not been reported.

In this study, the iNOS inhibition activity was determined by measuring the amount of nitrate in LPS-activated macrophage 264.7 cells. Cells were pre-treated with 40 $\mu \mathrm{g} / \mathrm{ml}$ of each fractions for $1 \mathrm{~h}$ and LPS $(1 \mu \mathrm{g} / \mathrm{mL})$ were added to stimulate the cells to produce NO. The iNOS inhibition rate (\%) of the $\mathrm{MeOH}$ extract and its fractions were shown in Table 1 , and cell viability was also tested in the same condition. The $\mathrm{MeOH}$ extract significantly reduced the formation of NO by $41.0 \%$. The hexane fraction effectively reduced the NO formation by $63.8 \%$ which was more effective than other three fractions. While the $\mathrm{MeOH}$, hexane, and EtOAc fractionsdid not affect the cell viability, the $\mathrm{CHCl}_{3}$ fraction was relatively cytotoxic with $26.4 \%$ cell viability at $40 \mu \mathrm{g} / \mathrm{mL}$.

Therefore, the hexane fraction was chromatographed to isolate the active substance. The two substances of ursolic acid $^{6}$ and phrymarolin $\mathrm{I}^{2}$ were identified by comparison of ${ }^{1} \mathrm{H}-\mathrm{NMR}$ and ${ }^{13} \mathrm{C}-\mathrm{NMR}$ spectroscopic data with literatures, as shown in Fig. 1. Phrymarolin I possessing the basic skeleton of 1,2-dioxygenated-3,7-dioxabicyclo[3.3.0]octane is known to have a larvicidal activity. ${ }^{7,8}$ The three compounds $\mathbf{3}, \mathbf{4}$, and $\mathbf{5}$ isolated from the $\mathrm{BuOH}$ fraction were identified as harpagide, ${ }^{11}$ haedoxancoside $\mathrm{A},{ }^{5}$ acteoside $^{12}$
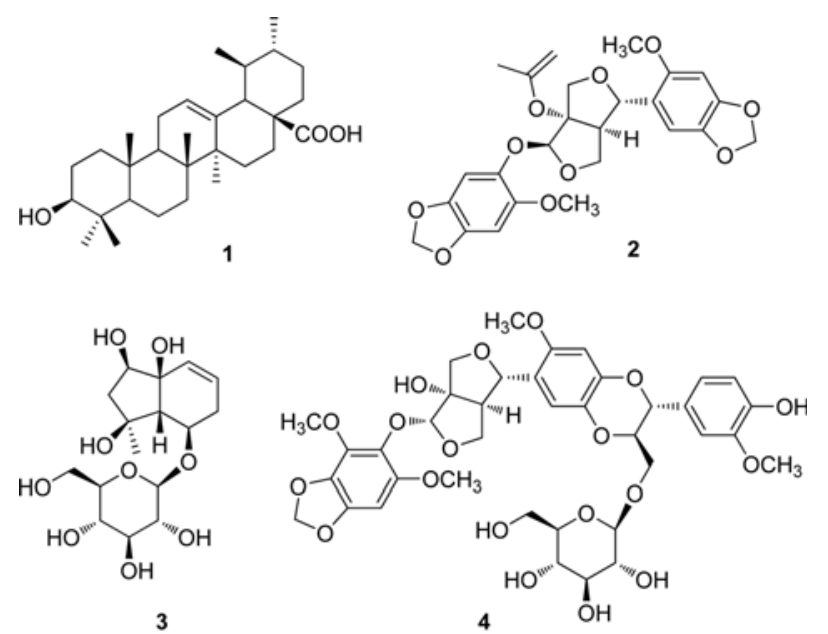

3

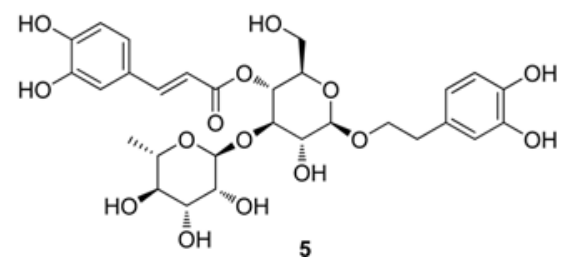

Fig. 1. Structure of compounds $\mathbf{1 - 5}$ isolated from $P$. leptostachya var. asiatica.

Table 2. Effect of compounds $\mathbf{1}$ - $\mathbf{4}$ obtained from P. leptostachya var. asiatica on NO formation in LPS-activated macrophage cells (test concentration of $40 \mu \mathrm{g} / \mathrm{mL}$ )

\begin{tabular}{ccc}
\hline \hline Compound & Inhibition rate (\%) & Cell viability (\%) \\
\hline Ursolic acid (1) & 80.6 & $-^{\mathrm{a}}$ \\
Phrymarolin I (2) & 30.2 & - \\
Haedoxancoside A (3) & 35.2 & - \\
Acteoside (4) & 25.6 & - \\
AMT $(0.2 \mu \mathrm{M})^{\mathrm{b}}$ & 82.4 & - \\
\hline
\end{tabular}

Footnote: $-^{\mathrm{a}}$, not cytotoxic; ${ }^{\mathrm{b}}$ AMT: 2-Amino-5,6-dihydro-6-methyl4H-1,3-thiazine

by ${ }^{1} \mathrm{H}-\mathrm{NMR}$ and ${ }^{13} \mathrm{C}-\mathrm{NMR}$ spectra. Of the five compounds isolated, harpagide and acteoside has not been reported from P. leptostachya var. asiatica.

The inhibition rate of the four compounds (ursolic acid, phrymarolin I, haedoxancoside A and acteoside) are shown in Table 2. The AMT (2-Amino-5,6-dihydro-6methyl-4H-1,3-thiazine), a known iNOS inhibitor, was used as a positive control. Among the four compounds, ursolic acid showed the highest inhibition rate (80.6\%), and other compounds showed inhibition rate lower than $50 \%$. Therefore, the inhibition of NO formation and cell viability of ursolic acid were further tested at 10, 20, and $40 \mu \mathrm{g} / \mathrm{mL}$, respectively (Fig. 2). The $\mathrm{IC}_{50}$ value was determined to be $20.8 \mu \mathrm{g} / \mathrm{mL}$, and the inhibition of $\mathrm{NO}$ 

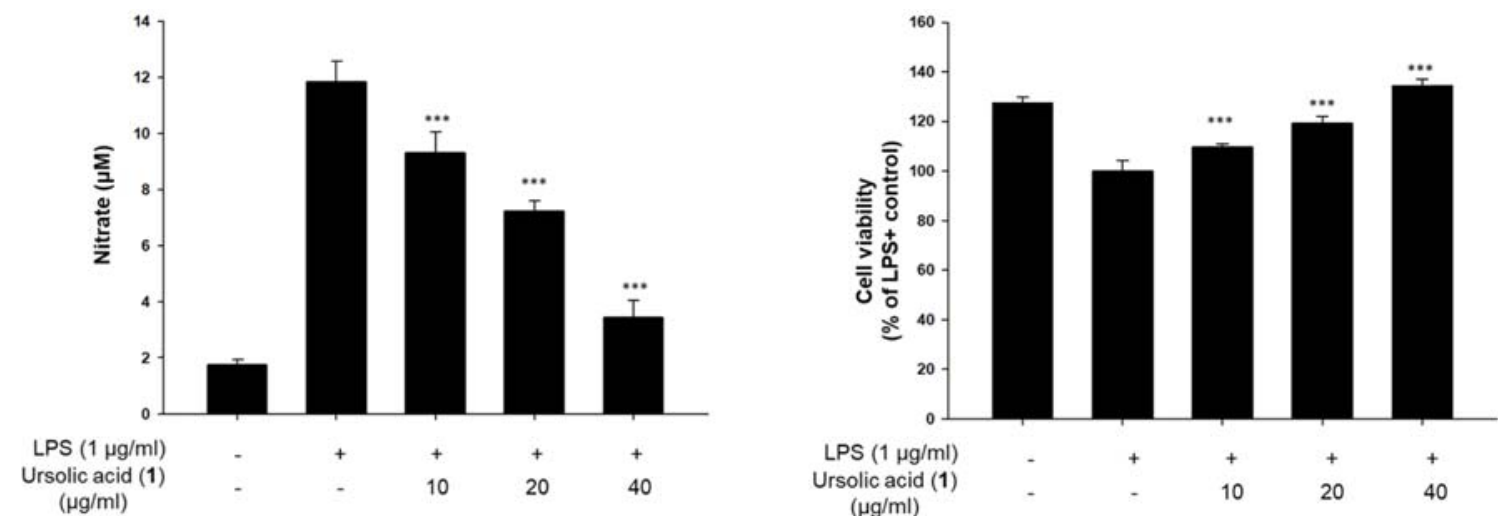

Fig. 2. Effect of compound 1 on NO formation in LPS-activated macrophage 264.7 cells. Cells were pretreated with different concentrations of ursolic acid and stimulated with LPS $(1 \mu \mathrm{g} / \mathrm{mL})$. The amount of nitrate was measured by Griess reaction. The cell viability was measured using MTT. The data are presented as the means \pm SD. $* P<0.05, * * P<0.01, * * * P<0.005$ by $t$-test.

production by ursolic acid was not derived from the cell viability.

Although the anti-inflammatory and inhibitory effects of NO formation by ursolic acid have been reported, ${ }^{14,15}$ the inhibitory activities of phrymarolin I and haedoxancoside A on NO formation are newly discovered in the present study. In conclusion, ursolic acid exhibited the most potent anti-inflammatory activity without cytotoxicity. In addition, harpagide and acteoside were first isolated from P. leptostachia var. asiatica

\section{Acknowledgments}

This research was supported by the Sangji University Research Fund, 2018.

\section{References}

(1) Jung, H. J.; Cho, Y. W.; Lim, H. W.; Choi, H.; Ji, D. J.; Lim, C. J. Biomol. Ther. 2013, 21, 72-78.

(2) Tanigichi, E.; Oshima, Y. Agric. Biol. Chem. 1972, 36, 1013-1025.

(3) Taniguchi, E.; Oshima Y. Agric. Biol. Chem.1972, 36, 1489-1496.
(4) Xiao, X.; Ji, Z.; Zhang, J.; Shi, B.; Wei, S.; Wu, W. Chem. Nat. Comp. 2013, 49, 21-23.

(5) Chen, C.; Zhu H.; Zhao, D.; Deng, J.; Zhang, Y. Helv. Chim. Acta 2013, 96, 1392-1396.

(6) Lee, S.; Min, B.; Kho, Y. Arch. Pharm. Res. 2002, 25, 652-654.

(7) Seo, S. M.; Park, I. K. Parasitol. Res. 2012, 110, 1849-1853.

(8) Park, I. K.; Shin, S. C.; Kim, C. S.; Lee, H. J.; Choi, W. S.; Ahn, Y. J. J. Agric. Food Chem. 2005, 53, 969-972.

(9) Singh, V. K.; Mehrotra, S.; Narayan, P.; Pandey, C. M.; Agarwal, S. S. Immunol. Res. 2000, 22, 1-19.

(10) Chesrown, S. E.; Monnier, J.; Visner, G.; Nick, H. S. Biochem. Biophys. Res. Commun. 1994, 200, 126-134.

(11) Manguro, L. O. A.; Lemmen, P.; Hao, P. Rec. Nat. Prod. 2011, 5, 147-157.

(12) Schlauer, J.; Budzianowski, J.; Kukulczanka, K.; Ratajczak, L. Acta Soc. Bot. Pol. 2004, 73, 9-15.

(13) Park, H. J.; Jung, W. T.; Basnet, P.; Kadota, S.; Namba, T. J. Nat. Prod. 1996, 59, 1128-1130.

(14) Kim, M. H.; Kim, J. N.; Han, S. N.; Kim, H. K. Immunopharmacol. Immunotoxicol. 2015, 37, 228-235.

(15) Li Q.; Dong, D. D.; Huang, Q. P.; Li, J.; Du, Y. Y.; Li, B.; Li, H. Q.; Huyan, T. Pharm. Biol. 2017, 55, 799-809.
Received August 15, 2018 Revised September 13, 2018 Accepted September 17, 2018 